\title{
CHANGING SCHOOL AFTER THE GLOBAL RECESSION: THE CASE OF LATVIA
}

\author{
Irēna Žogla \\ University of Latvia
}

\begin{abstract}
Latvia demonstrates common trends with the majority of the countries affected by the recession, as well as some peculiarities in overcoming the impact of the global economic and financial recession on education mainly due to an unbelievable austerity. Education in this country has suffered greatly, and its damage is adequate to the 67\% of the budget cuts between 2008 and 2011 (IZM, 2011). The article deals with the school improvement after the recession, recent implementation of innovations to cover the damages and catch up with the ideas of the Next Generation learning, to supply schools with the appropriate curricula and meeting the learners needs for their individual development and ability to find jobs, as well as appropriate for the school transition teachers' further professional development.
\end{abstract}

Keywords: financial recession; retention of learners; further developments of the school system and curricula; changes in educational management and leadership.

\section{Introduction}

To start with here is a saying of American Indians: 'If you do not know your destination any path will do.' Countries being severely affected by the last Global economic and financial recession report different damages and challenged innovations in their school systems. Meanwhile uncertainty of a possible further educational development still causes obstacles. Damages in the educational system are too deep for the country which by the beginning of the recession had been in a process of yet uncompleted crucial restructuring of the social sphere during the last two decades. Budget financing for education is close to critical already for several years, and it means that there is money almost only for poor salaries with very poor subsidies for the development. The latter decisively depends upon the revenue of the local bodies.

Several positions draw a picture of the state of matters: budget and salary cuttings, unemployment and uncertainty in the future work places, low payment for teachers' performance caused a large number of job emigrants, decrease of population, and retention of learners at all levels of education. In 2006/07 there were 1008 comprehensive schools with 532222 learners; in 2012/13 - there were only 832 comprehensive schools with 212433 learners. Accordingly, the number of learners in vocational schools has decreased for more than 12 thousand learners, as well as the number of tertiary students - from more than 131000 to less than 94500 (IZM, 2011).

Therefore there is a need to address the consequences to trace possible strategic and the nearest developments in education. There is also a need to assume the consequences of the severe austerity which make educational system balance between surviving and reverse in the development, as well as innovative efforts in schools of Latvia and also in the other countries to improve educational 
efficiency and get out of the hard times. Actually a deep investigation should follow the recession that is still threatened by underfinanced research in this country and also other scientific activities.

Therefore this article draws some prospective considerations on the background of theoretical analysis illustrated by some data from the Central Statistical Bureau, reports and statistics of the Ministry of education and science to spot out the destination and possible path to mitigate the adverse impact of the recession on school performance: gaining's before the recession, challenges for the changing school, essentialities of the curricula, teachers' professional quality, and expected redirection of school management.

\section{From work-place fillers to job-place creators}

Between 2008 and 2011 the budget support for education in Latvia lost $67 \%$ (IZM, 2011), and it had been accompanied by the decreasing resources of the households. Long-lasting severe austerity, low revenue, rising costs of services, medicine, goods, transport, education etc. delay well-being of the residents and encourage them to look for jobs outside the country. In spite of the comparatively rapid economic and financial recovering in Latvia the postausterity boosting of the labour market is still slow, and job migration from Latvia causes decrease of the work-force, as well as decreasing number of school learners and tertiary students.

There were 562 - 580 tertiary students per 10 thousand of residents in 2005/06; the number has fallen down to 467 in 2012/13. The same tendency hit also the vocational schools (CSB, 2013). In the rural areas 176 local schools (IZM, 2013) had been closed forcing districts to adopt cost-saving measures like bigger class sizes and fewer extracurricular activities. Financial cuttings have reached a critical level, and it cannot cover the growing needs of development.

The current process, if not re-directed, is contrasting with the important tendencies: by $2020,65 \%$ of all jobs will require postsecondary education and training beyond a secondary school education. This number has jumped significantly from 1973 when only $28 \%$ of all jobs required some form of postsecondary degree (Turner, 2013).

Enterprises following the aim of cheaper production and meeting the demands towards its quality will use the opportunity to make major investments in automation, digital and other modern technologies of production; and this tendency will cause higher demands towards professional quality of specialists, will call for considerably higher skills and appropriate quality of education. Consequently, tertiary and compulsory school education needs to be improved accordingly. The paradox is located in the strategies of enterprises and rising economy: on the one hand they need well prepared and trained, high skilled specialists and workers, on the other - they hesitate to invest in education (Pope, 2013). In this country the enterprises lack the needed income and money, also experience, to invest in education of working force. 
This trend is far from universal; many countries remain urgently focused on narrow skills and job-training while advocates in a broad range of places around the world hear employers demanding the "soft skills" - communication, critical thinking, and experience of working with diverse groups - a broad-based learning more effectively fits the current needs of modern social processes. These advocates argue their countries need job-creators, not just job-fillers. They think the biggest innovations come from well-rounded graduates - from empathetic engineers' (Pope \& Tang, 2013).

The knowledge society is already demanding towards well educated and capable graduates ready for life-long learning by targeted combining of formal and informal education, possibilities to reflect and learn at work, as well as boost experiences at their leisure time. The knowledge society is also highly demanding towards knowledge industries, knowledge production and knowledge management. The current situation seems to impose a dilemma: the knowledge industries especially in this digital age produce digital tools which have not been designed for learning and pedagogical purposes but which are used for knowledge acquisition by schools and universities - neither books, nor internet or recording techniques and digital technologies have been discovered and developed for learning and pedagogical purposes. Meanwhile pedagogies do use these sources as learning tools, even without prior investigation of their pedagogical values. University educators and school teachers have not investigated and defined the possibilities of the new technological tools and therefore they continue the usual pedagogical practice of transmitting knowledge to their learners by using new tools within old transmitting models (Laurrilard, 2002: 20).

Therefore there is little progress in the way we teach, despite the new possibilities. To improve our pedagogical practices we have to find differences between the curricula that teach what we know and those which teach how to come to know, as well as practice autonomous learning. Job-creators should start at schools by developing creative thinking and skills of self-conducted learning. The turning point for schools, therefore, is transforming from teaching domain to learning; this process is still underequipped by appropriate pedagogical tools and undermanaged by teachers and school managers.

\section{Challenged changes of school system}

Some twenty years ago Latvia had to overcome the technical unemployment; the current recession has introduced a reality, which can be called competencelagging unemployment. Therefore the educational system of this country faces a challenge of preparing the youth ready to jump over this gap which appears due to expanding demands of the job market alongside with the growing demands for skilled workers. J.Turner believes that over the next seven years, the largest job growth might occur in occupations that require so-called "middle skill" jobs 
or professional skills acquired after or parallel to the secondary education. The fastest-growing occupations and concentration of jobs will be healthcare, technology, engineering, science, as well as mathematics to operate the digital tools. It is estimated that about $75 \%$ of all jobs will soon require a postsecondary professional education (Turner, 2013).

These estimations prompt changes in school system and also in their curricula. Therefore OECD considers secondary education to be the "baseline" qualification needed in today's economy, with many of their indicators measuring the proportion of the population who hope to achieve or have achieved education beyond this baseline (CIEB, 2012). Meanwhile the generic secondary education is not sufficient for the school leavers to find jobs. The OECD found that labour income growth among highly educated people has contributed to more than half of GDP growth in OECD countries, whereas workers with less than a secondary education actually serve as a drag on labour income growth (CIEB, 2012). To urge school transition OECD suggest a number of new indicators discussed in the series Education at a Glance of 2012. The most important ones which indicate a country's growth and are demanding for the school development is put into suitable wording to meet the topicality of the principles for Latvia:

- Establishing of effective relationship between the global economy and education of the population also tracing how quality education influences economic growth, labour costs and earning power to attract the attention of the enterprises and targeted directing of school changes; the principle is not reached yet in its component regarding the enterprises' participating in preparing the school leavers basic practical skills to fit the job market.

- Expanding of social mobility of the learners, teachers and other specialists to grasp the increasing importance of quality education with educational attainment levels to reach high quality production and appropriate education; mobility should be boosted by coordinated efforts of schools, local bodies, enterprises, community where teachers are among the main agents in local areas. Therefore they need improved professional education by acquiring experiences of their colleagues in other countries (EU, 2010).

- To reach an appropriate proportion of the population who achieve education beyond the educational baseline of the secondary education; the principle is not appropriately attended yet at governmental and local levels regarding the quality needed for production and school leavers' employment.

- Reaching an effective balance between schools, local authorities, government, and parents in making the key decisions and creating autonomous developing and cooperative educational systems in communities; the starting stage is completed by transforming small country schools into multifunctional cultural centres of the communities. By now this initiative meets only preserving of country schools since a damaging for education financing practice 'money-follows-a-child' has been introduced. 
- Raising affectivity of the pre-school education to succeed on the later levels of education etc. (CIEB, 2012). In Latvia this level of education is being discussed for further improvements.

The recession is revolutionizing economy and education in the biggest part of the world while the problem in Latvia is located in the low speed and moneyconsuming reorganization of a number of secondary schools into secondary vocational schools to meet the challenge and prevent growing numbers of jobless school leavers. Besides, parents are not ready to accept secondary vocational schools due to the previous experience when this type of schools had ben associated with low quality of education. In order to follow the OECD principles and catch up with the above described tendencies of economy the traditional schools should undertake transition and develop two main types of secondary schools.

1. A reduced in number group of secondary schools will the aim of preparing their leavers for tertiary education in close cooperation with universities.

2. High quality secondary professional schools to offer their leavers:

- possibilities to acquire appropriate secondary education valid for possible further tertiary education;

- a cluster of basic "middle skills" of a branch or a couple of related branches of production which will enable the school leavers to start their job career because they will hold appropriate work practice at an enterprise and develop their work experience very much needed to be employed.

In fact, the problem is strongly demanding and deep since its solution involves the whole educational system and its management, multiple employers and boosting possibilities of preparing the youth for jobs, coupling schools with enterprises not only for financial support but, what is not the least, for targeted preparation of their leavers to enter the job market within the country and outside it. A so called 'learning exchange' or other similar activities should couple the school learners with the possible employers and the character of already existing and new openings of jobs, samples of skills which school leavers might need, as well as quality of education to attain the desired position. Initiated by the recession studies show how skills have become of greater strategic importance not only because of the demand for 'knowledge' workers, but due to the rapid growth of high skilled workers in emerging economies which are offered by transnational companies, the potential to create global skill webs - the full length of the value chain. The analysis also show how countries, in albeit different ways, have invested in education and exploited the latest technologies to enter the global competition for high skilled, value added products and services (Brown \& Lauder, 2011).

\section{The current crisis calls for re-visiting the school curricula}

Being a small country with a very sensitive economy in the making Latvia is strongly influenced by the global political, economic and financial motions. The problem is boosted by the current process of ideological consensus of 
neoliberals in the world that continue destabilization of markets followed by the financial crisis and the global recession of 2007 in the advanced liberal economies (Peters, 2011). This country experiences dependence on these motions and the dependence have also spread over education and the future of the school leavers who meet direct international competing for work places. Therefore Latvia's strategies in education cannot function without the global influences.

It is obvious that a country and its educational system should consider the novel approaches of combining secondary school and college or university education by gearing it toward the economic sectors to combine school and college/university curricula towards the most demanded professions and competences. 'The great skills race has begun' (Canda, 2013). Changes in the school system are only half the way. When recession and crisis occur, particularly on a vast scale, it challenges reflection. People who have become unemployed need to re-evaluate their abilities, career options and quality of education they have obtained before, as well as they expect provision of a targeted supportive system.

The current crisis also urges to re-visit the school and tertiary curricula. The recession has highlighted dis-connectedness between usually highly interconnected finances and industry, between the customers and education, as well as between educational curricula and work-force. Therefore education needs to seriously re-direct their programs. A good news is the recent issue (IZM, 2014) drawing the framework for the educational development for 20142020. It is a long-term conceptual document of a human development-oriented education as a model for the development of the country which accentualizes knowledge, skills, productive mind-set of the residents and due changes in education. Hopefully, the appropriate changes of the educational system follow - changes which will be based on the need of quality education instead of the existing poor amount of money as a priority to start thinking of education.

In Latvia like in the European countries and the USA schools have been practicing a liberal style of learning and broad education before specialization. "In the neo-liberal world with its economic problems broad-based learning, the liberal arts and sciences are losing favour with students". School educational expenses and "tuition is so high and the lingering economic distress so great that an education if not directly tied to an occupation is increasingly seen as a luxury. Elsewhere in the world, there is a growing emphasis on broader learning as an economic necessity. Recent changes have pushed back specialization, making more room for general education" (Pope \& Tang, 2013). This dilemma prompts that there is an urgent need to find an optimal proportion in curricula between general and professional education at schools; might be even several models offered by researchers, academics and teachers. 
The school curricula should therefore answer two clusters of complicated questions to choose and implement optimal models, and the implementation will not be targeted without appropriate research-based choices:

- How to combine and make interrelated generic knowledge and basis of practical skills of the learners to enable them for entering tertiary studies and obtaining practical skills? Should schools provide a range/clusters of the most needed skills during the school classes or should they change the traditional lessons' practices and expand out-of-class activities in enterprises with responsible attraction of the specialists there?

- How to combine the complexity of the needed skills, generic knowledge, deep understanding, and context knowledge with still existing curricula defined in the terms of school subjects?

To find appropriate answers and make decisions on school curricula there is a need to come to a common understanding and implementation of the following:

- The nature, definition and process of the New Generation learning and its characteristic features, as well as achievements at each level of school education. Learning should not be considered the target in itself - the learners' optimal developmental success should be achieved in learning.

- Didactic models appropriate for the New Generation learning to strike the targets of the learners' generic knowledge and practical skills, as well as achieve intellectual, emotional, social qualities of an autonomous learner ready for non-stop, life-long self-fulfilment.

- Teachers' professional education should be focussed on the development of reflective practitioners able to conduct inquiry-based didactic process with a special attention to dialogues, manage the transition of school teaching curriculum to a learning curriculum.

- The New Generation learning supported and personalized at school leads to the learners' individual meaningful achievements and development of their abilities of doing, communicating, cooperating, reflecting and responsible decision-making.

\section{Who and how will educate new managers?}

Accordingly, new quality of administration, management and deep leadership (Haregreaves, 2006) is required to achieve economic and educational competitiveness of our country. The tertiary education, therefore, will increase their activities towards the development of critical thinking of the specialists-inmaking, their social and other competences appropriate for life in multicultural settings. In recent times, especially during and after the recession learning to manage education strategically and organize a recession-proof schooling in this country have become critical topics for educational managers at all levels - from the level of the state to each small country school. School principals are constantly searching for new ways to boost financial support and minimize dependence from economic downturns, as well as avoid failures and/or preserve 
the personnel and the school as a cultural centre of the community. This activity is important, but not enough; effective conducting of the school transition from teaching domain to learning schools is a must for quality recession-proof schools.

Changes have started. More than 50 small country schools have become multifunctional community centres where teachers provide a wide range of service to the community. Certainly, it is a way out, but where could it lead and how far? Can it be a sustainable solution and open for the further effective development? To a certain extent yes, and still deep management changes are needed. First of all there is a need in competent conducting of the paradigm change and teachers' qualification in the transition from teaching to learning school - a time and energy consuming process demanding teachers' and principals' new mind-set and their acting as reflective practitioners.

It is worth addressing a well-known specialist in change management Harvard professor J. P. Kotter (1994) whose investigations pay attention to two rather different and closly related elements:

- There must be a deep analysis of the existing process, designing of the new one, creation of full set of resources needed to support the new process;

- The creation of an appropriate environment that will accept the change - the politics, the motivation, and culture in which significant change can occur.

Kotter (2007) has defined several stages of the conducted change process - a manager has to know that unfinished transition slowly revert the process back to the starting position and even to its lower quality. It happens when a team attends to developing a good process redesign but ignores the change management. Eight reasons why conducted transition fails might help the school leaders and principles to design and conduct the appropriate change of schools and their curricula. The list of Critical Mistakes includes the following reasons of failure (might be that the educational managers at all levels will better notice the destroying qualities to reach the appropriate changes):

An adequate sense of urgency is not established

No powerful guiding coalition is established

There is no clear, guiding vision

The vision is not communicated

Obstacles to the vision are not removed

There are no systematic efforts to create short term wins

Victory is declared too soon

Changes are not anchored in the corporate culture (Kotter, 1994).

\section{Discussion: Avoiding a boomerang effect}

The government's large cuts of spending in education are already having and will have, if not removed, even more serious consequences for the economy in the short, as well as in long term. Local authorities in school districts with damaged production even if experiencing currently increasing revenue have limited possibilities to afford appropriate investments in education and funding 
school projects. Business managers need political and educational support. Consequently, the school recovery, especially their targeted development is terminated; the already introduced initiatives towards the pedagogical paradigm change are also undermined.

Slow transition to learning schools in this country endangers educational reforms and their future impact on economy in different ways:

- Recruiting high quality teachers, reflective practitioners as one of the most important school-based determinant of the learners' success has become a problem right after the recession. Quality of schools impacts also the quality of the cultural processes in the areas and post-school vocational education.

- Production of learning materials is expensive and they often are materials for the teachers while the learners are unable to use them appropriately without teacher's assistance. Text-books and other materials must be designed for the New Generation of learning and designed first of all for the learners' optional activities which conduct their learning; by doing so they would facilitate the development of the learners' skills. Not the least is response to the changing learners' perception in the digital age, as well as their experience of surfing the internet.

- Quite many schools have increased class sizes for 2009-12 (thinking of educational improvement starts from money instead of a better quality of education) in spite of well-known regularity that smaller class sizes can boost the learners' achievements, especially in the early grades and for those with special needs. Lost opportunities usually follow the school leavers on the next stages of education.

- Expanded list of school subjects and learning time are also being discussed as a quantitative means for better achievements instead of the qualitative initiatives. The competence-oriented curriculum needs a well-prepared by teachers appropriate option of activities of the learners - a crucially important precondition of the learning pedagogical paradigm.

- A need for high-quality early education has geared a discussion on the age to start schooling - should it be at seven or at six. Experimental school programs for six-year-olds have been created while the essential point is not when to start what but how to educate six-year-olds and reach the best possible success in their development - be it kindergarten or school. Sevenyear old children at kindergartens and well-prepared teachers there is a precondition to keep high quality pedagogical process at kindergartens while lack of this age there might result in lowering quality level of kindergarten pedagogy and reducing it to nursing.

\section{References}

1. Brown, F., Lauder, H. (2011). Globalisation After the Recession: Corporate Strategies, Industrial Activism and the Future of Skills. Assessed January 12, 2014 at 
http://www.cardiff.ac.uk/socsi/contactsandpeople/phillipbrown/globalisationrecession.html

2. Chanda, N. (2013). The Great Skill Recession. Assessed January 12, 2014 at http://yaleglobal.yale.edu/content/great-skill-recession.

3. CIEB (Centre on International Educational Benchmarking). (2012). Global Perspectives: An Education at a Glance for the post-recession world. Assessed January 12, 2014 at $\mathrm{http} / /$ www.ncee.org/2012/10/global-perspectives-an-education-at-a-glance-for-the-postrecession-world/

4. Central Statistical Bureau of Latvia (CEB). (2013). Statistic on education (Latv.). Assessed January, 4, 2014. Assessed January 11, 2014 at www.cst.gov

5. EU, Education and Culture DG, OECD. (2010). Teachers' Professional Development. Europe in international comparison. Luxemburg: Office for Official Publications of the EU. ISBN 978-92-79-15186-6.

6. Hargreaves, D.H. (2006). A New Shape for Schooling? Cambridge: Mission of the Specialist Schools and Academies Trust.

7. IZM (2011). Pārskats par 2011.gadu. Assessed January, 10, 2014. At www.izm.gov. (Ministry of education and science. Review for 2011).

8. IZM (2013). Statistika. Assessed at www.izm.gov. January, 10, 2014.

9. IZM (2014). Izglītības attīstības Pamatnostādnes 2014.-2020.gadam. Assessed March 01, 2014 at www.izm.gov. (Ministry of educationa and science. The guidelines of educational development for 2014-2020).

10. Kotter, J.P. (1994). Leading Change. Why Transformation Efforts Fail. Harward Business Review. January, 1994.

11. Kotter, J.P. (2007). Leading Change. Why Transformation Efforts Fail. Harward Business Review. January, 2007.

12. Laurillard, D. (2002). Rethinking Teaching for the Knowledge Society. Assessed January 10, 2014 at https://net.educause.edu/ir/library/pdf/ffpiu017.pdf.

13. Peters, M.A. (2011). Neoliberalism and After?: Education, Social Policy, and the Crisis of Western Capitalism (Global Studies in Education) ISBN-10: 143311206X | ISBN-13: 978-1433112065 | Edition: 2. Assessed December 2, 2013 at http://www.amazon.com/Neoliberalism-After-Global-Studies-education/dp/143311206X.

14. Pope, J. \& Tang, D. (2013). AP IMPACT: Post-recession, higher ed paths diverge. Assessed December 10, 2013 at http://bigstory.ap.org/article/ap-impact-post-recessionhigher-ed-paths-diverge- 0 .

15. Pope, J. (2013). Recession Pushes Major Education Innovation, And Investors Are Watching. Assessed December 10, 2013 at http://www.huffingtonpost.com/ 2013/08/05/recession-education- innovation_n_3707177.html.

16. Turner, J. (2013). Jobs in a Post-Recession Workforce Require More Educated Workers: A Shared Plan to Get There. Assessed December 10, 2013 at $\mathrm{http}$ //opportunitynation.org/blog/entry/jobs-in-a-post-recession-workforce-require-moreeducated-workers-a-shared-p

\footnotetext{
Prof. Irēna Žogla University of Latvia, PPMF

Jūrmalas gatve, 74/76, Riga, Latvia,LV-1083

Irena.zogla@lu.lv
} 